Understanding Disability Policies 


\section{Understanding Disability Policies}

Robert F. Drake

$\underset{\text { palgrave }}{\underset{\text { macrillan }}{2}}$ 
All rights reserved. No reproduction, copy or transmission of this publication may be made without written permission.

No paragraph of this publication may be reproduced, copied or transmitted save with written permission or in accordance with the provisions of the Copyright, Designs and Patents Act 1988, or under the terms of any licence permitting limited copying issued by the Copyright Licensing Agency, 90 Tottenham Court Road, London W1P 9HE.

Any person who does any unauthorised act in relation to this publication may be liable to criminal prosecution and civil claims for damages.

The author has asserted his right to be identıfied as the author of this work in accordance with the Copyright, Designs and Patents Act 1988.

Furst published 1999 by MACMILLAN PRESS LTD

Houndmills, Basingstoke, Hampshire RG21 6XS

and London

Companies and representatives

throughout the world

ISBN 978-0-333-72427-9

DOI 10.1007/978-1-349-27311-9

ISBN 978-1-349-27311-9 (eBook)

A catalogue record for this book is avallable from the British Library.

This book is printed on paper suitable for recycling and made from fully managed and sustained forest sources.

Editing and origination by Aardvark Editorial, Mendham, Suffolk 
This book is dedicated to my parents Robert and Audrey Drake 


\section{Contents}

Acknowledgements $\quad \mathrm{x}$

1 Introduction 1

The structure of the book $\quad 2$

Part I: The Meaning of Disability AND

the Creation of Policy

2 Theoretical understandings of disability 9 Introduction 9

Defining disability: the 'personal tragedy' model 10

Ethics and the personal tragedy model 11

The social model of disability 13

The exercise of power 14

The state, power and the creation of policy 18

What is policy? 21

How is policy made? $\quad 22$

Conclusion 31

Part II: Disability Policy, Models and Development

3 Models of disability policy 35

Introduction $\quad 35$

A spectrum of approaches to disability policy 37

Citizenship 41

Conclusion 44

4 The development of disability policies in Britain 45

Introduction 45

The historical context $\quad 46$

$\begin{array}{ll}\text { Conclusion } & 67\end{array}$ 
5 Contemporary disability policies in Britain $\quad 68$

$\begin{array}{ll}\text { Introduction } & 68\end{array}$

Contemporary disability policies and social institutions $\quad 69$

$\begin{array}{ll}\text { Conclusion } & 91\end{array}$

6 Contemporary British policy in the international context $\quad 93$

Introduction 93

Negative policies: Nazi Germany and China 94

Contemporary Sweden: a maximal welfare state? 98

Australia: a hybrid welfare/civil rights approach 103

The United States: a civil rights approach 105

Conclusion: the United Kingdom's piecemeal approach in context

108

\section{Part III: Policy Outcomes and Disabled}

\section{People's Responses}

7 Social class and disability

Introduction

Social class and disability

What is 'class'?

Social class and the impact of disability policies

Conclusion

8 Gender and disability

Introduction

Differential treatment and impacts of policies on women and men

Responses to the impacts of disability policies

Policy impacts on gay and lesbian disabled people 
9 Minority ethnic communities and disability 148

Introduction 148

The disabled ethnic minority population $\quad 149$

The impacts of disability policies 151

The response of black and Asian disabled people $\quad 160$

$\begin{array}{ll}\text { Conclusion } & 161\end{array}$

10 Age and disability policies 163

Introduction 163

The population of older disabled people $\quad 163$

Policies and their outcomes 164

The concerns of older disabled people $\quad 165$

Older people with cognitive impairments 170

Responses of older people $\quad 171$

Older people and policy making $\quad 173$

$\begin{array}{ll}\text { Conclusion } & 177\end{array}$

11 Disabled people and the policy process 179

$\begin{array}{ll}\text { Introduction } & 179\end{array}$

Causes of exclusion $\quad 180$

Possible remedies: from exclusion to inclusion $\quad 183$

Methods adopted in seeking to influence policy 187

Obstacles in seeking to influence policy 192

Successes 195

Conclusion 195

12 Conclusions 197

Introduction $\quad 197$

Outcomes in perspective $\quad 199$

Prospects 200

Conclusion 206

$\begin{array}{ll}\text { Bibliography } & 207\end{array}$

$\begin{array}{ll}\text { Index } & 235\end{array}$ 


\section{Acknowledgements}

Our universities are underfunded and undervalued. Increasingly, research is judged in terms of the money it brings in rather than the benefits it confers. One feels deep gratitude therefore for being given the space and time to attempt a volume that may be assayed on its own merits. In particular, I appreciate the support of my colleagues at the Department of Social Policy, University of Wales, Swansea. Notwithstanding the inordinate pressures confronting them, Ken Blakemore, Anthea Symonds and Mike Sullivan gave freely of their advice, wisdom and experience, and heartened me throughout the whole process of writing this book. Equally, our social policy students relished the chance to turn the tables and criticise early drafts of chapters, and the magnificent Eryl Evans, with her usual serenity and aplomb, held back the administrative tide that threatened to swamp us all.

According to the pre-eminent Greek scholar H.D.F. Kitto, Aeschylus described his own work as being 'slices from Homer's banquet'. I have no hope of approaching Aeschylus' greatness, but may perhaps emulate his modesty by recognising how much my studies owe to the solicitous help of several distinguished colleagues. I should particularly mention the encouragement I have received over many years now from Professor Michael Oliver, Professor Len Barton, Dr Tom Shakespeare and Dr Colin Barnes. I am equally grateful to a host of other friends, some disabled, some not, in the academic, statutory and voluntary sectors here in Wales who freely gave me their advice and offered new insights. They discussed some of the thorny issues addressed in the book and challenged my misconceptions and prejudices. Accordingly, whatever degree of understanding this volume reveals, they have taught me. Any errors are, of course, entirely my own.

Next, I must thank several colleagues from library and information services who aided my search for much of the material used in the book. I am especially grateful to Lis Parcell at Swansea University Library, Sue Johnson at the Policy Studies Institute, Philip Pinto at the Commission for Racial Equality, Brenda Ellis from the Greater London Association of Disabled People, and Claire Williams at Mind Cymru.

Third, formal acknowledgements are due to those who granted permission to use copyright material. I am particularly grateful to 
Harvester Wheatsheaf for allowing me to adapt some of my ideas in the book Understanding Equal Opportunity Policies and to Carfax Publishing Limited (PO Box 25, Abingdon, Oxon, OX14 3UE) for permission to use material from my article on power and disabled people first published in Disability and Society. My thanks also go to the Office for National Statistics for permission to reproduce Tables 7.1 and 7.2, and to Dr Tom Shakespeare for allowing me to quote from two of his works, as well as for his kindness in reading and commenting on Chapter 8. I also owe thanks to Bill Bytheway for extensive and helpful comments on the material I use in Chapter 10.

For her infinite patience and sage advice, I am especially grateful to my editor at Macmillan, the superb Catherine Gray, and last but not least, I must also acknowledge the forbearance and support of my family - my parents and my partner Gillian - all of whom have now heard enough about disability policies to last them a lifetime.

Robert Francis DRAKE

Swansea 1998 